\title{
Bioaccumulation of Polybrominated Diphenyl Ethers by Tubifex Tubifex
}

\author{
Boris Kolar, ${ }^{1, *}$ Lovro Arnuš, ${ }^{1}$ Boštjan Križanec, ${ }^{1}$ Willie Peijnenburg ${ }^{2,3}$ \\ and Mojca Kos Durjava ${ }^{1}$ \\ ${ }^{1}$ National Laboratory of Health, Environment, and Food, Prvomajska 1, 2000 Maribor, Slovenia, \\ ${ }^{2}$ National Institute of Public Health and the Environment-RIVM, P.O. Box 1, 3720 BA Bilthoven, The Netherlands \\ ${ }^{3}$ University of Leiden, Center for Environmental Sciences, Leiden, The Netherlands \\ * Corresponding author: E-mail: boris.kolar@nlzoh.si \\ Phone +38624500155 Fax +38624500227
}

Received: 25-05-2016

\begin{abstract}
The selective uptake of polybrominated diphenyl ethers (PBDEs) by oligochaetes makes it possible to assess the bioaccumulation of individual congeners in commercial mixtures. Twenty-one congeners from three BDE commercial mixtures (TBDE-71, TBDE-79 and TBDE-83R) and as individual congeners (BDE-77, BDE-126, BDE-198 and BDE-204) were tested on Tubifex tubifex in accordance with the OECD TG 315 "Bioaccumulation in Sediment-Dwelling Benthic Oligochaetes". All the congeners that were spiked in the sediment were detected at the end of the uptake phase and at the end of the experiment. The bioaccumulation factor $(\mathrm{BAF})$, the kinetic bioaccumulation factor $\left(\mathrm{BAF}_{\mathrm{K}}\right)$ and the biotasediment accumulation factor (BSAF) were calculated, and indicate a high bioaccumulation potential for tri- to hexaBDEs and a lower bioaccumulation potential for hepta- to deca-BDEs. The penta-homologues BDE-99 and BDE-100 showed the highest BSAFs of 4.84 and 5.85 (BAFs of 7.34 and 9.01), while the nona- and deca-BDEs exhibit bioaccumulation in up to one-order-lower concentrations. The change in the bioaccumulation potential between the group of trito hexa-BDEs and hepta- to deca-BDEs correlated with the generally accepted molecular-mass threshold for the molecular transition through biological membranes $(700 \mathrm{~g} / \mathrm{mol})$.
\end{abstract}

Keywords: Bioaccumulation; polybrominated diphenyl ethers, BSAF; Tubifex tubifex

\section{Introduction}

Polybrominated diphenyl ethers (PBDEs) have been used as flame retardants for a large number of synthetic applications, such as building materials, furnishing textiles, and electronic equipment, in order to reduce the risk of fire. ${ }^{1}$ However, in 2003 the production and use of PBDEs was restricted in many parts of the world because of environmental problems and risks to human health.

PBDEs have a structure consisting of two benzene rings connected by an ether bond. The bromines substituted at positions 1 to 10 allow, in theory, 209 congeners. $^{2}$ PBDEs are categorized by their degree of bromination, where the term homologue is used to refer to a group of PBDEs with the same number of bromines (PBDEs containing five bromine atoms are, for example, referred to as
penta-BDEs). Based on the number of bromine substituents, there are 10 homologous groups of PBDEs (monobrominated through deca-brominated homologues). ${ }^{3} \mathrm{Hi}-$ storically, three major PBDE products have been commercially available on the global market, i.e., the penta-, octaand deca-BDEs. ${ }^{4}$ The commercial products are not pure substances; rather they are mixtures of congeners. For instance, the commercial product penta-BDE is a mixture of a tri-, tetra-, penta- and hexa-BDE, whereas octa-BDE consists of hexa-, hepta-, octa- and nona-BDE. In contrast to the commercial penta- and octa-BDEs products, commercial deca-BDE is a relatively pure mixture, composed predominantly of deca-BDE ${ }^{5}$. PBDEs are insoluble substances with moderate-to-high lipofilicity. Some of the physical and chemical properties of PBDEs are shown in Table 1. 
Table 1. PBDE homologues: molecular mass, log octanol-water partition coefficient $\left(\log \mathrm{K}_{\mathrm{OW}}\right)$ molecular size ( $\mathrm{D}_{\text {max.ave }}$-maximum average diameter) and estimated enthalpy change for the phase transition of the dissolved compound from octanol to water $\left(\Delta \mathrm{H}_{\mathrm{OW}}\right)$.

\begin{tabular}{|c|c|c|c|c|c|}
\hline $\begin{array}{c}\text { PBDE } \\
\text { homologues }\end{array}$ & Congener & $\begin{array}{l}\text { Molecular mass } \\
(\mathrm{g} / \mathrm{mol})\end{array}$ & $\log K_{\text {ow }}$ & $\begin{array}{l}\mathbf{D}_{\text {max. ave }} \\
(\mathbf{n m})^{\mathbf{f}}\end{array}$ & $\underset{(\mathrm{kJ} / \mathrm{mol})^{6}}{\Delta \mathbf{H}_{\mathrm{OW}}}$ \\
\hline tri & BDE-28 & 406.89 & $5.94^{\mathrm{a} 7} ; 5.53^{\mathrm{a} 8} ; 5.48-5.58^{\mathrm{a} 9}$ & 1.45 & 15 \\
\hline \multirow[t]{4}{*}{ tetra } & BDE-47 & 485.79 & $6.81^{\mathrm{a} 7} ; 6.11^{\mathrm{a} 8} ; 5.87-6.16^{\mathrm{a} 9}$ & & 20 \\
\hline & BDE-51 & 485.79 & & & \\
\hline & BDE-66/42 & 485.79 & & & \\
\hline & BDE-77 & 485.79 & & 1.45 & \\
\hline \multirow[t]{4}{*}{ penta } & BDE-99 & 564.68 & $7.32^{\mathrm{a}^{\mathrm{7}}} ; 6.61^{\mathrm{a} 8} ; 6.64-6.97^{\mathrm{a} 9}$ & 1.45 & 20 \\
\hline & BDE-100 & 564.70 & $6.51^{\mathrm{a} 8}$ & & \\
\hline & BDE-119 & 564.70 & & & \\
\hline & BDE-126 & 564.70 & & 1.44 & \\
\hline \multirow[t]{2}{*}{ hexa } & BDE-153 & 643.62 & $7.90^{\mathrm{a} 7} ; 7.13^{\mathrm{a} 8} ; 6.86-7.93^{\mathrm{a} 9}$ & 1.45 & 20 \\
\hline & BDE-154 & 643.62 & $7.82^{\mathrm{a} 8}$ & & \\
\hline \multirow[t]{2}{*}{ hepta } & BDE-180 & 722.50 & $8.27^{\mathrm{a}} ; 7.49^{\mathrm{b} 8}$ & 1.45 & 25 \\
\hline & BDE-183 & 722.50 & & 1.45 & \\
\hline \multirow[t]{4}{*}{ octa } & BDE-197 & 801.30 & & & 25 \\
\hline & BDE-198 & 801.30 & & & \\
\hline & BDE-203 & 801.47 & $7.90^{\mathrm{b} 8}$ & & \\
\hline & BDE-204 & 801.47 & & 1.46 & \\
\hline \multirow[t]{3}{*}{ nona } & BDE-206 & 880.27 & $8.30^{\mathrm{b} 8}$ & 1.47 & 25 \\
\hline & BDE-207 & 880.27 & & 1.41 & \\
\hline & BDE-208 & 880.27 & & 1.47 & \\
\hline deca & BDE-209 & 959.17 & $8.70^{\mathrm{b}} ; 9.97^{\mathrm{a} 9}$ & 1.45 & 25 \\
\hline
\end{tabular}

${ }^{\mathrm{a}}$ measured ${ }^{\mathrm{b}}$ calculated ${ }^{\mathrm{f}}$ calculated with OASIS ${ }^{10}$

In line with the intelligent testing strategy ${ }^{11}$ to make environmental risk assessments of large numbers of chemicals more efficient and to reduce the number of tests on vertebrates such as fish and amphibians, the aquatic annelids have become a frequently used test species. ${ }^{12}$ The oligochaeta species Tubifex tubifex has proven to be a good model organism to replace aquatic vertebrate species such as fish when assessing the bio-accumulative properties of substances. ${ }^{13}$ In contrast to fish, marine polychaeta and freshwater oligochaeta present a surrogate for sedimentdwelling organisms that allows a relevant assessment of the impact of chemicals on the lower part of the food chain. These organisms are exposed to pollutants by an uptake from pore water, the ingestion of detritus, and through skin contact with contaminants bound to the sediment particles. ${ }^{14}$ Therefore, sediment-dwelling organisms represent a worst-case scenario for bioaccumulation effects. ${ }^{15}$ Experimental results indicated that the combined exposure of fish to the lipophilic chemicals in water and contaminated oligochaete T. tubifex as a food source leads to a significantly greater bioaccumulation than an exposure to water only. ${ }^{16}$

The purpose of the study was to generate reliable experimental data on bioaccumulation in oligochaetes for the relevant PBDE congeners in accordance with the standardized test method. The performance and test results fulfill the quality criteria for an environmental risk assessment in the legal frameworks for chemicals (Regulation (EC) No. 1907/2006; REACH). The bioaccumulation fac- tor $(\mathrm{BAF})$, kinetic bioaccumulation factor $\left(\mathrm{BAF}_{\mathrm{K}}\right)$, and the biota-sediment accumulation factor (BSAF) were calculated based on the measured concentrations of congeners in the sediment and tested organisms.

Twenty-one BDE congeners were selected in accordance with their analytical possibilities, REACH relevance, structural representativeness and the relevance based on their toxicity and physicochemical properties. The dataset obtained in this study was then extended by predicting the bioconcentration (BCF) and biomagnification factors. ${ }^{18}$ In addition, the available data indicated that the BAF values can subsequently be used to calculate the toxicity endpoints, either using experimentally obtained critical body burdens (CBBs) for the various PBDEs, or by using QSAR approaches for predicting the $\mathrm{CBBs}^{19}$. This study was conducted as part of the CADASTER project (Case Studies on the Development and Application of InSilico Techniques for Environmental Hazard and Risk assessment) (http://www.cadaster.eu/).

\section{Materials and Methods}

A 28-day test of bioaccumulation with T. tubifex was performed with selected PBDEs to determine the bioaccumulation of substances according to OECD TG 315 "Bioaccumulation in Sediment-Dwelling Benthic Oligochaetes". ${ }^{20}$ The tested worms were exposed using many routes for the uptake, including direct contact, ingestion 
of contaminated sediment particles, porewater and overlying water. However, the main endpoint of the test according to OECD TG 315 was the bioaccumulation factor (BAF) as the ratio between the concentration of the contaminant in the tested animal and the concentration of the contaminant in the sediment. The design of the test does not allow us to consider other routes of exposure.

\section{1. Test Compounds}

Three BDE commercial mixtures (penta-DE-71, octa-DE-79, and deca-DE-83R) and four individual congeners (BDE-77, BDE-126, BDE-198, and BDE-204) were purchased from Wellington Laboratories, Canada. The supplier certified each mixture and compound with a Certificate of Analysis (CofA) and guaranteed a minimum chemical purity of $98 \%$. A labeled internal standard solution (Catalogue number: EO-5277) and a labeled injection internal standard solution (Catalogue number: EO-5275) were purchased from Cambridge Isotope Laboratories, Andover, USA. Penta-DE-71 is a mixture of approximately 28\% BDE-47, 43\% BDE-99, 8\% BDE-100, 6\% BDE-153, and 4\% BDE-154. BDE-49 and BDE-66/42 account for approximately $1 \% .^{21}$ The main constituents of the octa-DE-79 are the congeners BDE-183 (44\%) and BDE-153 (14\%), followed by BDE-154 (2\%). The nonaand deca-analogues are present in concentrations below $1 \%{ }^{22}$ In contrast to the penta-DE-71 and octa-DE-79, the commercial mixture deca-DE-83R consists predominantly of deca-BDE (97-98\%) and a smaller fraction of nona-BDE $(0.3-3 \%){ }^{23}$

The solvents dichloromethane, hexane and toluene (ENVISOLV for the analysis of dioxins, furans and PCBs) were purchased from Sigma Aldrich, Germany. The anhydrous sodium sulphate and potassium hydroxide were purchased from J. T.Baker, Deventer, Netherlands. The silica gel $\left(\mathrm{SiO}_{2}\right.$, mesh 60$)$ and the concentrated sulfuric acid were purchased from Sigma Aldrich, Germany.

\section{2. Preparation of Sediment}

Artificial sediment was prepared as recommended by OECD TG $315 .^{20}$ The peat content was $2 \%$ of the dry weight so as to correspond to the average level of organic content in natural sediment. The sediment consisted of quartz sand (obtained from Termit Domžale, Slovenia), kaolinite clay (obtained from Pika, Ljubljana, Slovenia), and finely ground sphagnum peat (from gardening stores). As a food source we added finely ground (particle size $\leq$ $0.5 \mathrm{~mm}$ ) leaves of stinging nettle (Urtica sp.). To achieve good mixing of the constituents, de-ionized water was added (conductivity $<10 \mu \mathrm{S} / \mathrm{cm}$ ), representing $46 \%$ of the total volume of the mixture. The percentage of the dry constituents in the artificial sediment is given in Table 2. In order to determine the dry weight, the sediment was weighed after the excess water was decanted. The sediment was dried at $105{ }^{\circ} \mathrm{C}$ for 2 hours and weighed again. The ratio of the dry weight to the wet weight for the sediment was 0.7. The total organic carbon (TOC) was measured and expressed in terms of the sediment's wet and dry weights.

The artificial sediment was spiked with a BDE mixture by coating the quartz-sand fraction. A BDE solution was prepared to provide a final total concentration of $35-70 \mu \mathrm{g}$ per gram of wet sediment. The quartz-sand fraction of the sediment was soaked with this solution in a shallow glass vessel. After the solvent had evaporated, the quartz sand was mixed with the other constituents of the sediment. The test-substance concentrations for the whole sediment were more than 10 times lower than the LOECs for burrowing activity. ${ }^{25}$ The spiked sediment was then added to the test chamber and rotated on a wheel at $4 \mathrm{rpm}$ for 5 days to allow partitioning of the test substance between the sediment and the aqueous phase.

\section{3. Culture of Test Organisms}

A permanent single-species culture of the tubificid oligochaetes T. tubifex was obtained from a fish-food supplier and was cultured over several years at $142{ }^{\circ} \mathrm{C}$ and a light regime of approximately $250 \mathrm{~lx}$ for 16 hours per day. The stock culture was maintained on artificial sediment, with tap water flowing through the system. The oligochaetes were fed on aquarium cyprinid food twice a week. The cultures of the oligochaetes were kept in flat containers of 50-100 L with a height of $25 \mathrm{~cm}$. The containers were loaded with a layer of wet artificial sediment to a depth of approximately $4 \mathrm{~cm}$, which made possible the natural burrowing behavior of the oligochaetes. A tap-water flow of $3 \mathrm{~L} /$ hour formed a layer approximately $8 \mathrm{~cm}$ abo-

Table 2. Percentage of dry constituents for the artificial sediment ${ }^{20}$

\begin{tabular}{llc}
\hline Constituent & Characteristics & $\begin{array}{c}\text { weight percent } \\
\text { of dry sediment (\%) }\end{array}$ \\
\hline Peat & Ground sphagnum peat & 2 \\
Quartz sand & Grain size: particles $0.05-0.200 \mathrm{~mm}$ & 66 \\
& Grain size: particles $0.180-0.350 \mathrm{~mm}$ & 10 \\
Kaolinite clay & Kaolinite content $>30 \%$ & 22 \\
Food source & Powdered leaves of stinging nettle (Urtica sp.) & 0.4 \\
$\mathrm{CaCO}_{3}$ & $\mathrm{CaCO}_{3}$, pulverised, chemically pure & 0.1 \\
\hline
\end{tabular}

Kolar et al.: Bioaccumulation of Polybrominated Diphenyl Ethers ... 
ve the sediment. The water body was gently aerated using an aquarium air stone.

\section{4. Performance of the Test}

The bioaccumulation experiments were carried out in a temperate chamber. The replicate test vessels $(700 \mathrm{~m}$ $\mathrm{L}$ glass cup) were incubated at $20 \pm 2{ }^{\circ} \mathrm{C}$. Each of the test vessels contained a $2-\mathrm{cm}$ layer of spiked artificial sediment $(150 \mathrm{~g}), 1.2 \mathrm{~g}$ of oligochaetes and $500 \mathrm{~mL}$ of tap water. The maximum load of oligochaetes was 1-2 individuals $/ \mathrm{cm}^{2}$ of sediment surface. Control chambers were each loaded with uncontaminated sediment and $1.2 \mathrm{~g}$ of oligochaetes. For each sampling, two replicate test chambers were assembled. The animals were kept under artificial daylight for 16 hours per day.

Before the test, adult oligochaetes of the same age class (10-12 weeks) were collected from the culture by sieving the sediment through a $1-\mathrm{mm}$ mesh that retained adult individuals. The animals were weighed and transferred to the pre-weighed replicate test chambers. An acclimation period of 4 days was required, since the temperature conditions of the test were different to the conditions in the culturing vessel. No reproduction was observed during the test. For the determination of the BDE concentration in the sediment, oligochaetes and water, sampling intervals were set at $0,1,2,7,14,21$ days, and on day 28 , when the uptake phase was terminated. During each sampling two replicate test vessels and the two control vessels were removed from the incubation chamber. The temperature, dissolved oxygen and $\mathrm{pH}$ of the overlying water were measured in the test and control vessels. The controls were re-incubated, while $200 \mathrm{~mL}$ of overlying water, approximately $10 \mathrm{~g}$ of wet sediment and the oligochaetes were removed from each of the replicates for analytical purposes.

The experiments to determine the time course of the elimination kinetics were conducted immediately after the uptake phase. The remaining replicate test chambers were removed from the incubation box on sampling days 29 , $30,33,36$ and 40, and processed as described above. After the rinsing, the oligochaetes were weighed and inserted into pre-weighed test chambers containing uncontaminated artificial sediment and tap water. All subsequent procedures were performed according to the methods used during the uptake phase.

Four experimental trials were conducted on the BDE commercial mixtures and on selected individual congeners. In the first and second experiments, the pentaBDE commercial mixture (DE-71) of 10 congeners and the octa-BDE commercial mixture (DE-79) of eight congeners were tested, respectively. The third experiment involved the individual congeners BDE-77 and BDE-126. The last experiment was performed on the individual congeners BDE-198 and BDE-204, together with the decaBDE (DE-83R) commercial mixture of four congeners. No toxic response was observed during the test.

\section{5. Sample Preparation}

The sediment samples were centrifuged at 2640 $\mathrm{xG}$-force for $5 \mathrm{~min}$ at room temperature. Centrifuged sediment samples of approximately $5 \mathrm{~g}$ (the exact weight was recorded) were spiked with an internal standard mixture containing ${ }^{13} \mathrm{C}_{12}$-labeled isomers. A two-step, ultrasound extraction was performed, first with a mixture of toluene:acetone $(10 \mathrm{ml}: 30 \mathrm{ml})$, and second with a mixture of toluene:acetone $(30 \mathrm{ml}: 10 \mathrm{ml})$. The extracts were combined and dried over anhydrous sodium sulfate. A clean-up of the extract was performed on a mixed column (layers: silica gel/sulfuric acid, silica gel/KOH and silica gel). Sample extracts were concentrated prior to the GC/MS analysis to $40 \mu \mathrm{l}$ and transferred to an auto-sampler vial.

The lipid content of the worms was determined according to the Weibull-Stoldt ${ }^{26}$ method in the batch prior to and after the test. For a determination of the dry weight the oligochaetes were weighed after excess water had been removed by gently touching the animals against the edge of the holding dish. The animals were dried at 105 ${ }^{\circ} \mathrm{C}$ for 2 hours and weighed again.

Prior to the analysis, the oligochaetes were rinsed with tap water in a petri dish to remove the sediment particles. Then they were weighed and stored at minus $20 \pm$ $2{ }^{\circ} \mathrm{C}$ for at least one night. Next day, $400 \mathrm{pg}$ of an internal standard mixture containing ${ }^{13} \mathrm{C}_{12}$-labeled isomers was added to the oligochaetes (approx. $1 \mathrm{~g}$ ) in a test tube and mixed with anhydrous sodium sulfate ( $3 \mathrm{~g})$. A two-step, ultrasonic extraction was performed with dichloromethane $(2 \times 10 \mathrm{ml})$. The extracts were combined and dried over anhydrous sodium sulfate. A clean up of the extract was performed on a mixed column (layers: silica gel/sulfuric acid, silica gel/KOH and silica gel). Sample extracts were concentrated prior to the GC/MS analysis to $40 \mu \mathrm{l}$ and transferred to an auto-sampler vial.

Water samples $(200 \mathrm{ml})$ were spiked with an internal standard mixture containing ${ }^{13} \mathrm{C}_{12}$-labeled isomers. A twostep, liquid-liquid extraction was performed with dichloromethane $(2 \times 40 \mathrm{ml})$. The extracts were combined and dried over anhydrous sodium sulfate. A clean up of the extracts was performed on a mixed column (layers: silica gel/sulfuric acid, silica gel/KOH and silica gel). The sample extracts were concentrated prior to the GC/MS analysis to $40 \mu \mathrm{l}$ and transferred to an auto-sampler vial.

\section{6. Analytical Method}

The concentrations of the BDEs in the sediment, $T$. tubifex and water were determined by high-resolution gas chromatography coupled with high-resolution mass spectrometry (HRGC/HRMS).

The GC-HRMS was performed with a HP 6890 GC (Hewlett-Packard, Palo Alto, CA, USA) coupled to a Finnigan MAT 95XP (Finnigan, Bremen, Germany) high-resolution mass spectrometer. The GC separation was performed 
on a Zebron ZB-5HT INFERNO column (Phenomenex), $15 \mathrm{~m} \times 0.25 \mathrm{~mm}$ I.D. with a film thickness of $0.10 \mu \mathrm{m}$.

An aliquot $(2 \mu \mathrm{L})$ of sample extract was injected into the GC system in pulsed splitless mode at $250{ }^{\circ} \mathrm{C}$. The mass spectrometer operated in the electron impact ionization mode using selected ion monitoring (SIM) at a minimum resolution of 8000 . The samples were analyzed for the BDE concentrations using the isotope-dilution or internal-standard method based on the US EPA 1614 protocol. In addition to daily sensitivity and relative response factor (RRF) checks, the mean RRF was regularly re-evaluated for each congener.

\section{7. Determination of BAF}

In the four series of tests the BAF was calculated as the ratio of the concentration of the test substance in the test organism, $\mathrm{C}_{\text {org }}$, and the sediment, $\mathrm{C}_{\text {sed }}$, at steady state (Equation 1).

$$
B A F=\frac{C_{\text {org }}}{C_{\text {sed }}}
$$

To describe the time course of the uptake of the BDE$\mathrm{s}$ with a one-compartment model, equation 2 was used:

$$
C_{\text {org }}=\frac{k_{u p}}{k_{e l}} * C_{s e d}\left(1-e^{-k_{e l t} t}\right)
$$

where $\mathrm{k}_{\text {up }}$ is the uptake-rate constant in the tissue (g sediment $* \mathrm{~kg}^{-1}$ organism $*$ day $^{-1}$ ) and $\mathrm{k}_{\mathrm{el}}$ is the elimination-rate constant $\left(\mathrm{d}^{-1}\right)$ at time point $(\mathrm{t})$ of the uptake phase.

When a steady state is achieved during the uptake phase, equation 2 can be simplified (Equation 3):

$$
C_{\text {org }}=\frac{k_{u p}}{k_{e l}} * C_{\text {sed }}
$$

When equilibrium is not achieved during 28 days, the bioaccumulation factor can also be calculated as the ratio of the uptake- and elimination-rate constants assuming first-order kinetics (Equation 4).

$$
B A F_{K}=\frac{k_{u p}}{k_{e l}}
$$

For an interspecies comparison of bioaccumulation, the Biota-Sediment Accumulation Factor (BSAF) as a normalized version of the BAF should be used ${ }^{27,28}$. The BSAF is the lipid-normalized concentration of a test substance in the test organism divided by the organic-carbonnormalized concentration of the substance in the sediment at steady state, calculated as follows (Equation 5):

$$
B S A F=B A F * \frac{f_{o c}}{f_{l i p}}
$$

When the test oligochaetes are transferred from a contaminated sediment-water system to a system free of the test substance, the accumulated substance can be eliminated from the animal's body. If data points plotted against time indicate a constant exponential decline of the test substance's concentration in the animals, a one-compartment model can be used to describe the time course of the elimination (Equation 6):

$$
C_{\text {org }}(t)=C_{\text {org }} * e^{-k_{\text {el }}} e^{t}
$$

$\mathrm{C}_{\text {org_- }}(\mathrm{t})$ is the average concentration in the oligochaetes on day $\mathrm{t}$ of the elimination phase and $\mathrm{C}_{\text {org }}$ is the average concentration in the oligochaetes at steady state on day 28 of the uptake phase.

The equations presented here are taken from OECD TG 315. ${ }^{20}$ GraphPad Prism 5.04 was used to calculate the $\mathrm{BAF}$ and $\mathrm{BAF}_{\mathrm{K}}$ values.

\section{Results}

No mortality among the tested oligochaetes, as well as no deviation in burrowing activity in comparison to the control, was observed in the four series of tests. Thus, the validity criteria according to the OECD TG $315^{20}$ were met. The relative standard deviation (RSD) for the BAF in the test replicates was generally below $30 \%$, which is acceptable for this type of study. The bioaccumulation kinetics during 28 days of uptake and 12 days of elimination of the BDEs was plotted against the time course. The congeners BDE-153, BDE-154, and BDE-183 were present in different concentrations in both the penta-DE-71 and octa-DE-79 mixtures. Similarly, the deca-DE-83R and the octa-DE-79 commercial mixtures contained the congeners BDE-207 and BDE209. The uptake of the congeners BDE 153 and BDE 154, and congeners BDE 197 to BDE 209 did not reach a steady-state plateau within the exposure period of 28 days. As the absence of a steady state apparently leads to an underestimation of the bioaccumulation potential of the substances, ${ }^{29}$ the kinetic bioaccumulation factor $\left(\mathrm{BAF}_{\mathrm{K}}\right)$ was calculated.

The elimination-rate constant $\left(\mathrm{k}_{\mathrm{el}}\right)$ in the uptake phase proved to be a reliable indicator of a steady-state plate$\mathrm{au}$ in the uptake phase. When the $\mathrm{k}_{\mathrm{el}}$ was higher, equal, or approaching a value of 0.1 , the steady-state plateau was achieved in the timeframe of the test and the calculation of the BAF was a reliable estimation of the bioaccumulation. A significantly lower $\mathrm{k}_{\mathrm{el}}$ than the value of 0.1 indicated that the theoretical steady-state plateau would be reached way beyond the time frame of the test. In this case, the $\mathrm{BAF}_{\mathrm{K}}$ was more reliable for an estimation of the bioaccumulation potential.

When the elimination-rate constant $\left(\mathrm{k}_{\mathrm{el}}\right)$ was approaching 1 , the term $\mathrm{e}^{-\mathrm{kel}{ }^{*} \mathrm{t}}$ was approaching 0 and, con- 
sequently, the BAF become similar or equal to the $\mathrm{BAF}_{\mathrm{K}}$. The BAF was lower than the kinetic value when $\mathrm{k}_{\mathrm{el}}$ was approaching 0 and the term $\mathrm{e}^{-\mathrm{kel} * \mathrm{t}}$ was approaching 1 . Within the timeframe of the test the steady-state plateau was not reached for the hexa, nona, and deca congeners. Three characteristic graphs of the uptake and elimination of the BDE congeners in relation to the $\mathrm{k}_{\mathrm{el}}$ are shown in Figure 1. In the time course of the bioaccumulation of BDE-51 and BDE-100 (test 1; technical mixture DE-71) the $\mathrm{k}_{\mathrm{el}}$ was $\geq 0.1$ and the steady-state plateaus were reached for both congeners. The BDE-203 (test 2; technical mixture DE-79) shows an example when the $\mathrm{k}_{\mathrm{el}}$ is $<0.1$, and the steady state could be expected to be way beyond the timeframe of the test. The mean values of the concentrations measured for the oligochaetes in each of the two replicate test chambers were plotted, with error bars representing the corresponding standard deviation (SD).
The measured lipid content of the tested animals was $1.9 \pm 0.2 \mathrm{mg} / \mathrm{kg}$ and did not vary significantly during the test, nor between the batches from different test series. The dry-to-wet weight ratio for the tested T. tubifex was 0.131 . The total organic carbon (TOC) content was $1.25 \pm$ $0.1 \mathrm{mg}$ for the wet weight and $1.73 \pm 0.06 \mathrm{mg} / \mathrm{kg}$ for the sediment dry weight. The biota-sediment accumulation factor (BASF) calculation for the congeners that reached the steady-state bioaccumulation plateau was based on the BAF. When the elimination constant rate $\left(\mathrm{k}_{\mathrm{el}}\right)$ was lower than 0.1 the BSAF was calculated based on the $\mathrm{BAF}_{\mathrm{K}}$. Results for the bioaccumulation of the tested BDEs based on the wet weight of sediment and the tested animals are given in Table 3.

According to OECD TG 315, the test is terminated when either $10 \%$ of the concentration measured in the oligochaetes on day 28 of the uptake phase is reached, or after a maximum duration of 10 days of depuration. Excee-

Table 3. The concentration of the BDE in T. tubifex and in the spiked sediment on day 28 and the bioaccumulation factor BAF, kinetic bioaccumulation factor $\mathrm{BAF}_{\mathrm{K}}$ and sediment-biota normalized accumulation factor (BSAF) presented with a standard deviation.

\begin{tabular}{|c|c|c|c|c|c|}
\hline $\begin{array}{l}\text { Commercial mixture/ } \\
\text { Congeners }\end{array}$ & $\begin{array}{c}\text { T. tubifex at day } \\
\text { 28-uptake } \\
C_{\text {org }}(\mu \mathrm{g} / \mathrm{kg} \mathrm{ww})\end{array}$ & $\begin{array}{c}\text { Sediment at day } \\
28 \text {-uptake } \\
\mathrm{C}_{\text {sed }}(\mu \mathrm{g} / \mathrm{kg} \mathrm{ww})\end{array}$ & BAF & ioaccumulatior & BSAF \\
\hline \multicolumn{6}{|c|}{ DE-71 } \\
\hline BDE-28 & $1.20 \pm 0.15$ & $0.18 \pm 0.03$ & $6.57 \pm 0.36$ & $6.58 \pm 0.39$ & $4.34 \pm 0.60$ \\
\hline BDE-47 & $77.00 \pm 9.22$ & $11.60 \pm 0.99$ & $6.64 \pm 1.05$ & $5.55 \pm 0.54$ & $4.38 \pm 0.55$ \\
\hline BDE-51 & $0.93 \pm 0.25$ & $0.13 \pm 0.10$ & $6.91 \pm 0.28$ & $7.84 \pm 0.49$ & $4.56 \pm 1.92$ \\
\hline BDE-66/42 & $4.11 \pm 0.61$ & $0.59 \pm 0.11$ & $6.98 \pm 0.45$ & $7.73 \pm 0.76$ & $4.61 \pm 0.79$ \\
\hline BDE-99 & $87.94 \pm 0.48$ & $11.98 \pm 2.02$ & $7.34 \pm 0.60$ & $5.34 \pm 0.03$ & $4.84 \pm 0.37$ \\
\hline BDE-100 & $46.01 \pm 8.56$ & $5.11 \pm 1.06$ & $9.01 \pm 2.53$ & $10.47 \pm 0.20$ & $5.95 \pm 1.24$ \\
\hline BDE-119 & $0.38 \pm 0.04$ & $0.06 \pm 0.02$ & $6.54 \pm 0.44$ & $9.16 \pm 0.11$ & $4.31 \pm 0.82$ \\
\hline BDE-153 & $9.73 \pm 1.18$ & $2.56 \pm 0.63$ & $3.80 \pm 0.62$ & $4.64 \pm 0.58$ & $3.06 \pm 0.38^{\mathrm{a}}$ \\
\hline BDE-154 & $13.85 \pm 2.24$ & $2.43 \pm 0.31$ & $5.71 \pm 0.98$ & $8.01 \pm 1.60$ & $5.29 \pm 1.06^{\mathrm{a}}$ \\
\hline BDE-183 & $0.05 \pm 0.01$ & $0.15 \pm 0.01$ & $0.36 \pm 0.16$ & $0.82 \pm 0.10$ & $0.24 \pm 0.01$ \\
\hline \multicolumn{6}{|c|}{ DE-79 } \\
\hline BDE-153 & $15.00 \pm 0.20$ & $4.60 \pm 0.97$ & $3.30 \pm 0.66$ & $4.07 \pm 0.24$ & $2.69 \pm 0.16^{\mathrm{a}}$ \\
\hline BDE-154 & $3.36 \pm 0.12$ & $0.73 \pm 0.22$ & $4.83 \pm 1.54$ & $5.75 \pm 0.56$ & $3.80 \pm 0.37^{\mathrm{a}}$ \\
\hline BDE-180 & $0.21 \pm 0.40$ & $0.53 \pm 0.83$ & $0.39 \pm 0.04$ & $0.46 \pm 0.03$ & $0.26 \pm 0.03$ \\
\hline BDE-183 & $7.13 \pm 0.01$ & $13.91 \pm 0.04$ & $0.51 \pm 0.05$ & $0.47 \pm 0.05$ & $0.34 \pm 0.07$ \\
\hline BDE-197 & $7.93 \pm 0.93$ & $16.35 \pm 1.79$ & $0.49 \pm 0.11$ & $0.59 \pm 0.06$ & $0.39 \pm 0.04^{\mathrm{a}}$ \\
\hline BDE-203 & $2.68 \pm 0.56$ & $3.41 \pm 0.21$ & $0.79 \pm 0.23$ & $0.98 \pm 0.19$ & $0.65 \pm 0.12^{\mathrm{a}}$ \\
\hline BDE-207 & $1.88 \pm 0.73$ & $12.49 \pm 0.17$ & $0.15 \pm 0.07$ & $0.19 \pm 0.03$ & $0.13 \pm 0.02^{\mathrm{a}}$ \\
\hline BDE-209 & $0.38 \pm 0.15$ & $1.46 \pm 0.01$ & $0.26 \pm 0.02$ & - & - \\
\hline \multicolumn{6}{|c|}{ Individual congeners } \\
\hline BDE-77 & $60.31 \pm 1.31$ & $11.20 \pm 3.47$ & $5.39 \pm 0.12$ & $5.14 \pm 0.25$ & $3.55 \pm 1.11$ \\
\hline BDE-126 & $45.25 \pm 0.84$ & $7.95 \pm 2.54$ & $5.69 \pm 0,11$ & $5.75 \pm 0.60$ & $3.75 \pm 1.20$ \\
\hline \multicolumn{6}{|c|}{ DE-83R and individual congeners BDE-198, BDE-204 } \\
\hline BDE-198 & $19.38 \pm 0.34$ & $10.13 \pm 0.98$ & $1.92 \pm 0.15$ & $2.03 \pm 0.89$ & $1.34 \pm 0.59^{\mathrm{a}}$ \\
\hline BDE-204 & $12.47 \pm 0.65$ & $9.68 \pm 0.82$ & $1.29 \pm 0.04$ & $2.97 \pm 1.93$ & $1.71 \pm 0.93^{\mathrm{a}}$ \\
\hline BDE-206 & $0.73 \pm 0.01$ & $1.01 \pm 0.03$ & $0.72 \pm 0.16$ & $1.18 \pm 0.68$ & $0.78 \pm 0.44^{\mathrm{a}}$ \\
\hline BDE-207 & $0.89 \pm 0.08$ & $0.91 \pm 0.14$ & $0.97 \pm 0.06$ & $4.91 \pm 16.40$ & $1.41 \pm 1.68^{\mathrm{a}}$ \\
\hline BDE-208 & $0.56 \pm 0.03$ & $0.33 \pm 0.26$ & $1.67 \pm 0.19$ & $4.74 \pm 6.10$ & $2.14 \pm 1.64^{\mathrm{a}}$ \\
\hline BDE-209 & $16.89 \pm 0.70$ & $24.79 \pm 0.73$ & $0.68 \pm 0.03$ & $0.86 \pm 0.28$ & $0.93 \pm 0.57^{\mathrm{a}}$ \\
\hline
\end{tabular}

${ }^{a} \mathrm{BSAF}$ is calculated based on $\mathrm{BAF}_{\mathrm{K}}$ 

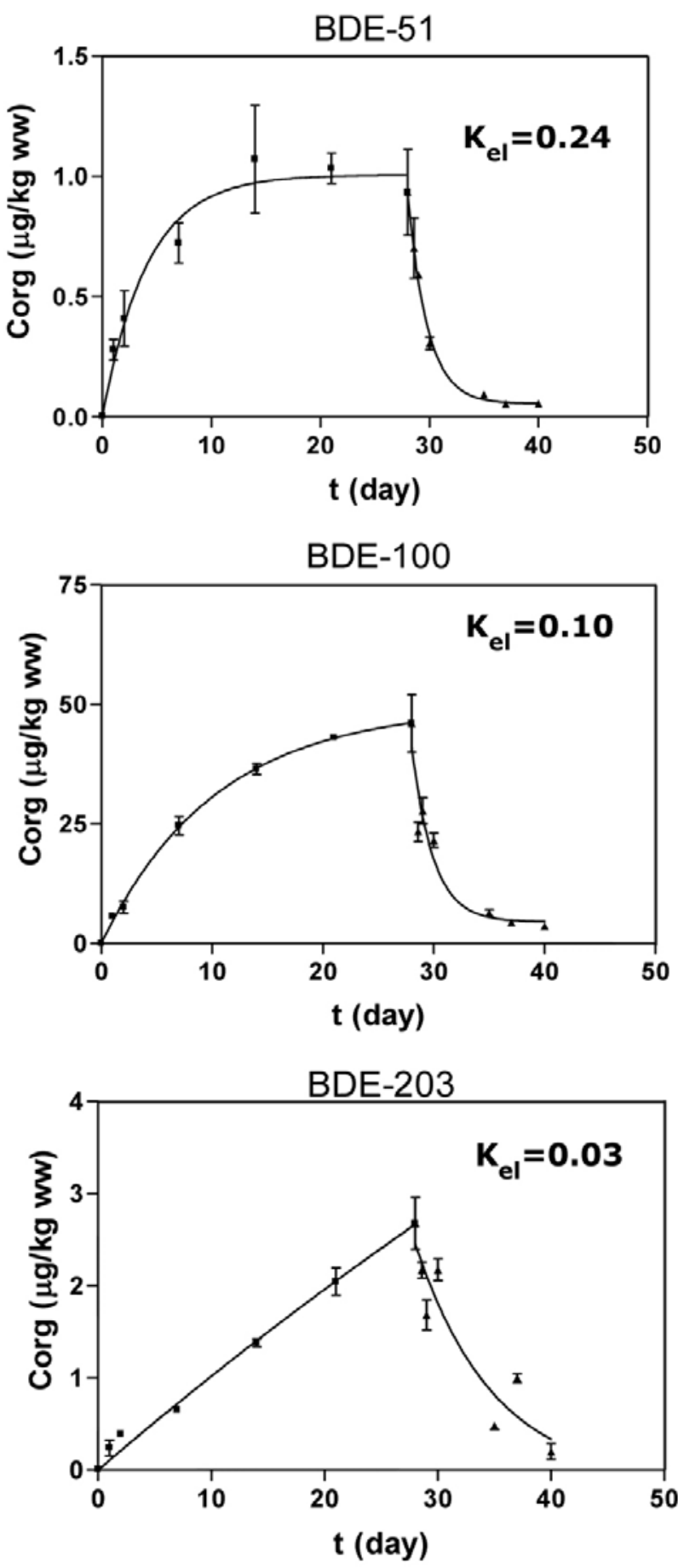

Figure 1. Time courses of the uptake and elimination of three PBDE congeners in T. tubifex in relation to $\mathrm{k}_{\mathrm{el}} \cdot \mathrm{k}_{\mathrm{el}} \geq 0.1$ indicates that the congeners reach a steady-state plateau in the test animal. Filled squares with error bars represent the measured concentrations on the sampling day.

ding the $10 \%$ threshold was observed for BDE 198 and BDE 209. After 10 days of the elimination phase these congeners were still present in the amounts $18.8 \%$ and $23.5 \%$ of the concentration measured on day 28 , respectively.

\section{Discussion}

The testing of the bioaccumulation of commercial mixtures of PBDEs combined with individual congeners was possible due to the selective uptake of PBDE congeners by the oligochaetes. ${ }^{30,31}$ The sediment was spiked with 21 congeners from three BDE commercial mixtures (TBDE-71, TBDE-79 and TBDE-83R) and with individual congeners (BDE-077, BDE-126, BDE-198, and BDE-204). All of the spiked congeners were detected in increasing concentrations in the test animals during and at the end of the test. These results lead to the conclusion that the accumulated BDEs undergo only a little or no transformation in the oligochaetes, which is particularly relevant in studies of the lower trophic levels of aquatic as well as of terrestrial ecosystems. The difference between the bioaccumulation of BDEs in sediment-dwelling oligochaetes (T. tubifex) and in fish on the higher tropic level was demonstrated in a water/sediment microcosm system by Tian et al. ${ }^{32}$ The simple digestive tract and metabolic system of the oligochaetes mean a relatively low metabolic capacity to debrominate BDEs. At the end of 80 days of exposure to the tri-, tetra-, penta-, hexa-, hepta-, and nona-BDE homologues, all 11 monitored BDE congeners could be quantified in worms, while only 5 of them were found in fish fillet and fish liver.

The results of the tests on oligochaete T. tubifex presented in Table 3 and Figure 2 show distinct differences in bioaccumulation for the two groups of BDE homologues ("bioaccumulation gap"). The BSAF for tri- to hexa-BDEs varied between 5.95 and 2.69 (on average 4.34) and in the hepta- to deca-homologues between 2.14 and 0.13 (on average 0.95 ). Similar conclusions were drawn by Tian et al. ${ }^{32}$ In the 80 -day microcosm study the BSAF for tri- to hepta-BDEs varied between 5.89 and 1.09 (on average 3.46), while a distinctive bioaccumulation gap appeared between the octa- (BSAF of 0.99 ) and nona- to deca-homologues (BSAF in the range 0.05-0.01, on average 0.3).

Several studies describe the differences in bioaccumulation between the tri- to hexa- and the hepta- to decaBDE homologues in sediment-dwelling or soil-dwelling annelids. For instance, the oligochaeta Lumbricus variegates exposed to a sediment spiked with BDEs accumulated tetra-, penta-, and hexa-BDEs, but the uptake of the deca congener BDE-209 was. ${ }^{33}$ A study on earth worms (Eisenia fetida) in soil spiked with the commercial BDE products DE-71 and DE-79 brought a similar conclusion. The uptake of the congeners BDE-47, BDE-99, BDE-100, BDE-153, BDE-154 was ten times higher than the uptake of the congener BDE-183. ${ }^{31}$ Nevertheless, in the same study it was suggested that even large molecules can be taken up by oligochaetes from the soil. The bioaccumulation of BDEs by the marine polychaete Nereis virens showed the predominance of penta-BDE-47, BDE-99 and BDE-100 followed by hexa-BDE-153 and BDE-154 in 


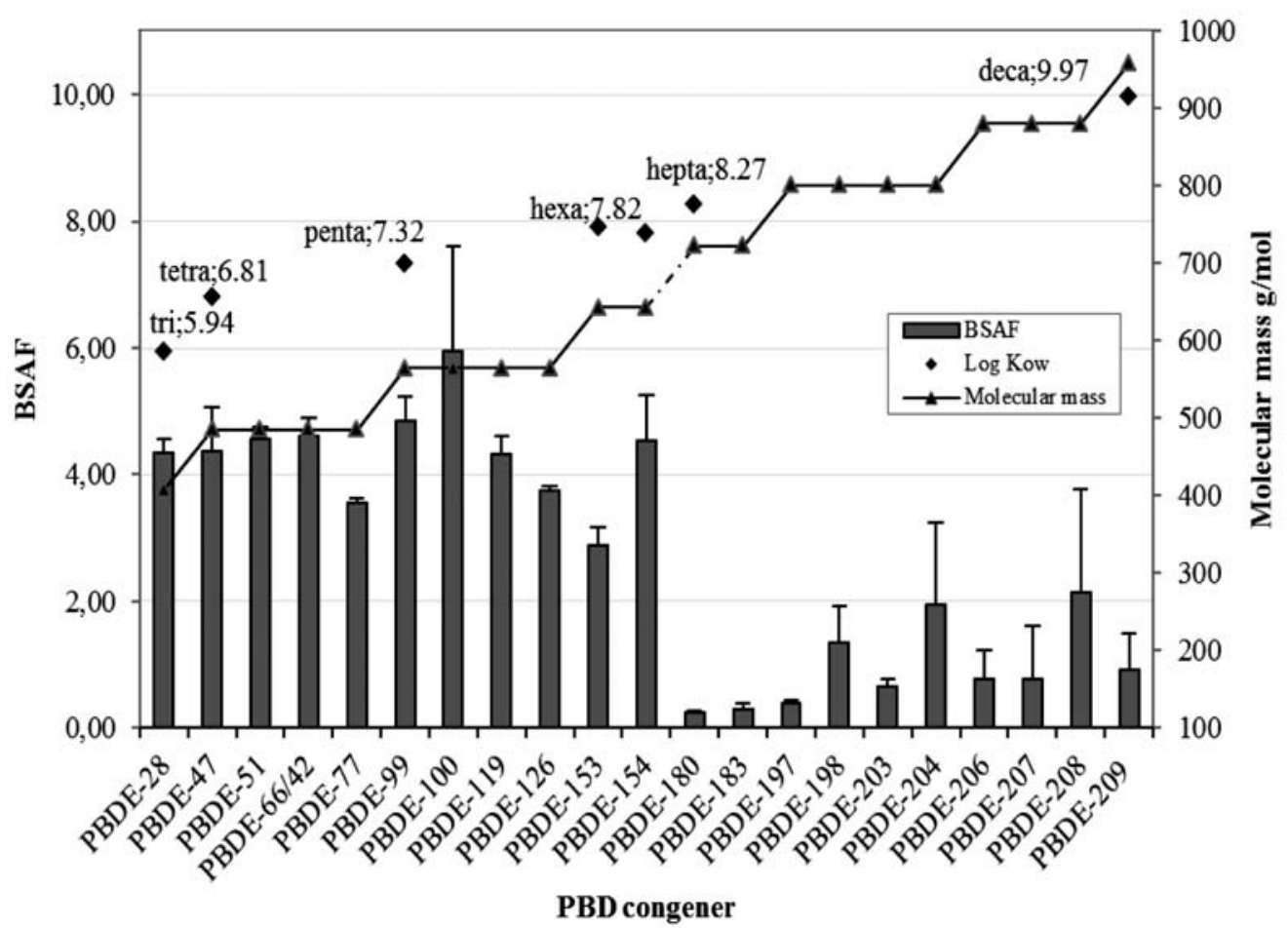

Figure 2. The biota-sediment assessment factor (BSAF) of tri- to deca-homologues of the BDEs in relation to the molecular mass and the measured $\log \mathrm{K}_{\mathrm{OW}}$. The dotted line indicates the bioaccumulation gap between the hexa- and hepta-homologues.

spiked artificial sediment. The accumulation of congeners with higher bromination was limited in a spiked matrix, while nearly no accumulation was registered in estuarine sediment. $^{30}$

The change in the bioaccumulation potential related to the increasing bromination of BDEs can be explained by the impact of the molecular weight, lipophilicity, enthalpy change in the transition between media and probably by the size of the molecules, which precludes large congeners from crossing the cell membranes in organisms. On the other hand, the bioavailability of extremely lipophilic substances generally decreases because of the stronger bond with the organic matter in the sediment and the lower solubility in water, digestive fluid and body surface. $^{34,35}$

Large organic molecules cannot passively diffuse through the phospholipid bilayer of the cell membrane. ${ }^{31}$ Therefore, the cross-membrane transport of molecules such as BDEs is replaced by exocytosis and endocytosis. Dimitrov $^{36}$ justified the existence of a transition point for the change in the mechanism of the uptake of chemicals. The threshold value of $1.5 \mathrm{~nm}$ for the size of the molecules is very comparable with the cell-membrane architecture.

The test according to OECD TG 315 for testing bioaccumulation in sediment-dwelling benthic oligochaetes is not designed to study the bioavailability of bio-accumulative substances. It is, therefore, difficult to assess the impact of lipophilicity on the bioaccumulation potential of tri- to hexa-congeners and the low bioavailability of hep- ta- to deca-congeners due to a strong bond to the artificial sediment particles. The comparison of the bioaccumulation dynamics of BDE congeners with the size of the molecules did not help to explain the biodynamics of the BDE congeners either. The values for the average maximum diameter $\left(\mathrm{D}_{\text {-max ave }_{\text {ave }}}\right.$ ) calculated with the program OASIS (Table 1) for the range of tri- to deca-BDE molecules are close to the threshold value of $1.5 \mathrm{~nm}$ and vary between 1.44 and $1.47 \mathrm{~nm} .{ }^{10}$ The size of the molecules generally did not correlate with increasing bromination or with the bioaccumulation potential of the BDEs.

The change in bioaccumulation potential between the hexa- and hepta-BDEs in our study correlates with the molecular-mass threshold for penetration through the cell membrane and the estimated enthalpy change. Molecular mass is used as a good descriptor for the upper limits of the pharmacological activity of molecules and it is commonly assumed that a low bio-accumulative potential is related to compounds having molecular weights close to or above $700 \mathrm{~g} / \mathrm{mol} .{ }^{10,37}$ The threshold molecular mass of $700 \mathrm{~g} / \mathrm{mol}$ is between hexa-BDEs (molecular mass of $643.62 \mathrm{~g} / \mathrm{mol}$ ) and hepta-BDEs (molecular mass of $722.50 \mathrm{~g} / \mathrm{mol}$ ), and so is the bioaccumulation gap (Figure 2).

A possible explanation for the bioaccumulation gap could be based on the thermodynamic properties of BDE$\mathrm{s}$. The proposed enthalpy change for the phase transition of the dissolved compound from octanol to water $\left(\Delta \mathrm{H}_{\mathrm{OW}}\right)$ is assumed to be 15,20 , and $25 \mathrm{~kJ} / \mathrm{mol}$ for the tri-, tetra- to hexa- and hepta- to deca-homologues, respectively. ${ }^{6}$ The 
decreased bioaccumulation of hepta- to deca- in regard to the tri- and tetra- to hexa-BDEs can be interpreted with the larger energy input that is needed for higher brominated BDEs in the transition between media; in our case between the organic matter in the sediment (dissolved organic carbon) and the digestive fluid.

In our study the elimination-rate constant for the hexa- and octa- to deca-BDEs approaches 0 , which indicates that the time to achieve a steady-state plateau in the oligochaetes is way beyond the time frame of 28 days. The hepta-homologues (BDE-180 and BDE-183), however, did reach the steady-state plateau in the tested oligochaetes. In the study we could not explain the reason for such behaviour of the congeners. Kraaij ${ }^{15}$ showed a relation between the long contact time and the bioavailability of lipophilic chemicals in sediment. The BSAF for PCB congeners (PCB 138, PCB 153, and PCB 156) in T. tubifex exposed to the spiked sediment was slowly increasing over nearly 1000 days. Tubificidae have a relatively long life span of more than 3 years, ${ }^{38}$ therefore, a slow and steady uptake of octa-, nona-, and deca-BDEs can, similar to PCBs, last for several months if not for the whole of their life cycle.

\section{Conclusion}

The freshwater oligochaete T. Tubifex selectively accumulated 21 congeners from three commercial mixtures (TBDE-71, TBDE-79 and TBDE-83R) and a mixture of four BDE individual congeners (BDE-077, BDE-126, BDE-198 and BDE-204), which were spiked with artificial sediment. The increasing concentrations of congeners in the test animals during the test indicated that the accumulated BDEs undergo only a little or no transformation in oligochaetes. The bioaccumulation factor (BAF), the kinetic bioaccumulation factor $\left(\mathrm{BAF}_{\mathrm{K}}\right)$ and the normalized biota sediment accumulation factor (BSAF) were determined in four series of tests, indicating a high bioaccumulation potential for the tri- to hexa-BDEs, whereas the bioaccumulation of the hepta- to deca-BDEs was considerably lower. A comparison of our results with the data on bioaccumulation in other species of annelids shows a similar bioaccumulation gap between these two groups of BDEs. Although the test according to OECD TG 315 "Bioaccumulation in Sediment-Dwelling Benthic Oligochaetes" ${ }^{20}$ is not designed to study the bioavailability and bioaccumulation dynamics of tested substances, we come to the conclusion that the molecular mass and enthalpy change for the phase transition from octanol to water correlates with the change of the bioaccumulation potential between the tri- to hexa- and hepta- to deca-homologues.

We can confirm that annelids such as terrestrial and freshwater oligochaetes and marine polychaetes are reliable surrogate species that reflect the bioavailability of sediment-associated lipophilic substances.

\section{Acknowledgments}

This study was part of the CADASTER project founded by the European Commission within the Seventh Research Framework Programme (project number 212668). The report on the testing of BDEs is available at http://www.cadaster.eu/node/110.

\section{References}

1. R. V Kuiper, A. D. Vethaak, R. F. Cantón, H. Anselmo, M. Dubbeldam, E.-J. van den Brandhof, P. E. G. Leonards, P. W. Wester and M. van den Berg, Chemosphere, 2008, 73, 195-202.

http://dx.doi.org/10.1016/j.chemosphere.2008.04.079

2. K. Mizukawa, H. Takada, I. Takeuchi, T. Ikemoto, K. Omori and K. Tsuchiya, Mar. Pollut. Bull., 2009, 58, 1217-1224. http://dx.doi.org/10.1016/j.marpolbul.2009.03.008

3. ATSDR, Toxicol. Profiles, 2004, 1-564.

4. D. Chen and R. C. Hale, Environ. Int., 2010, 36, 800-811. http://dx.doi.org/10.1016/j.envint.2010.05.013

5. L. S. Birnbaum and D. F. Staskal, Environ. Health Perspect., 2004, 112, 9-17. http://dx.doi.org/10.1289/ehp.6559

6. A. Palm, E. Brorström-Lundén and K. Breivik, TemaNord 2004:554, 2004, 77.

7. E. Braekevelt, S. a Tittlemier and G. T. Tomy, Chemosphere, 2003, 51, 563-567. http://dx.doi.org/10.1016/S0045-6535(02)00841-X

8. C. B. Wania, F. and Dugani, Environ. Toxicol. Chem., 2003, 22, 1252-1261.

http://dx.doi.org/10.1002/etc.5620220610

9. I. Watanabe and R. Tatsukawa, in Proceedings of the Workshops on Brominated Flame Retardants, ed. N. C. I. (KEMI), 1990, pp. 63-71.

10. D. N. Brooke and M. T. D. Cronin, UK Environ. Agency, 2009, 125.

11. J. Bruijn de and E. Fabjan, Toxicol. Lett., 2008, 180, S16.

12. T. Hutchinson, NC3Rs, 2008, 14, 1-11.

13. T. B. Reynoldson, S. P. Thompson and J. L. Bamsey, Environ. Toxicol. Chem., 1991, 10, 1061-1072. http://dx.doi.org/10.1002/etc.5620100811

14. G. R. Lotufo and S. W. Pickard, Bull. Environ. Contam. Toxicol., 2010, 85, 348-351. http://dx.doi.org/10.1007/s00128-010-0088-8

15. R. Kraaij, Utrecht University, 2001.

16. P. Egeler, M. Meller, J. Roembke, P. Spoerlein, B. Streit and R. Nagel, Hydrobiologia, 2001, 463, 171-184. http://dx.doi.org/10.1023/A:1013155709158

17. The European Parliament and the Council of the European Union, Off. J. Eur. Union, 2006, 1396/1.

18. K. Mansouri, V. Consonni, M. K. Durjava, B. Kolar, T. Öberg and R. Todeschini, Chemosphere, 2012, 89, 433-444. http://dx.doi.org/10.1016/j.chemosphere.2012.05.081

19. A. J. Hendriks, T. P. Traas and M. A. J. Huijbregts, Environ. 
Sci. Technol., 2005, 39, 3226-3236. http://dx.doi.org/10.1021/es048442o

20. OECD/OCDE, 315, 2008, 33. Mislim, da to ni vredu citirano, predlagam naslednji način zapisa: OECD, OECD Guideline for the Testing of Chemicals No. 315, 2008, 33 .

21. U.S. Environmental Protection Agency, EPA/635/R-07/006F, 2008, 74.

22. U.S. Environmental Protection Agency, EPA/635/R-07/007F, 2008, 42.

23. European chemichals Bureau, EUR 20402 EN, 2002, 17, 279.

24. L. Bielská, I. Hovorková, K. Komprdová and J. Hofman, Environ. Pollut., 2012, 163, 1-7. http://dx.doi.org/10.1016/j.envpol.2011.12.009

25. P. Egeler, J. Römbke, M. Meller, T. Knacker and R. Nagel, Hydrobiologia, 1999, 406, 271-280. http://dx.doi.org/10.1023/A:1003723831588

26. F. M. Matissek R, Steiner G, in Lebensmittelanalytik, Springer-Verlag Berlin Heidelberg, 4.th editi., 2009, pp. 33-34.

27. G. Tracey and D. Hansen, Arch. Environ. Contam. Toxicol., 1996, 30, 467-475. http://dx.doi.org/10.1007/BF00213397

28. L. P. Burkhard, P. M. Cook and M. T. Lukasewycz, Environ. Toxicol. Chem., 2010, 29, 230-236. http://dx.doi.org/10.1002/etc. 25

29. B. Beek, S. Böhling, U. Bruckmann, C. Franke, U. Jöhncke and G. Studinger, in Bioaccumulation - New Aspects and
Developments, ed. B. Beek, Springer Berlin / Heidelberg, 2000, vol. 2J, pp. 235-276.

30. S. L. Klosterhaus, E. Dreis and J. E. Baker, Environ. Toxicol. Chem., 2011, 30, 1204-1212. http://dx.doi.org/10.1002/etc.497

31. X. Liang, S. Zhu, P. Chen and L. Zhu, Environ. Pollut., 2010, 158, 2387-2392. http://dx.doi.org/10.1016/j.envpol.2010.04.008

32. S. Tian, L. Zhu, J. Bian and S. Fang, Environ. Sci. Technol., 2012, 46, 2951-2958. http://dx.doi.org/10.1021/es204011k

33. S. Ciparis and R. C. Hale, Environ. Toxicol. Chem., 2005, 24, 916-925. http://dx.doi.org/10.1897/04-179R.1

34. S. L. Klosterhaus and J. E. Baker, Environ. Toxicol. Chem., 2010, 29, 860-8. http://dx.doi.org/10.1002/etc.103

35. D. P. Weston and L. M. Mayer, Environ. Toxicol. Chem., 1998, 17, 830-840. http://dx.doi.org/10.1897/1551-5028(1998)017<0830: COIVDF $>2.3 . \mathrm{CO} ; 2$

36. S. D. Dimitrov, N. C. Dimitrova, J. D. Walker, G. D. Veith and O. G. Mekenyan, Pure Appl. Chem., 2002, 74, 18231830. http://dx.doi.org/10.1351/pac200274101823

37. A. Covaci, S. Harrad, M. a-E. Abdallah, N. Ali, R. J. Law, D. Herzke and C. a de Wit, Environ. Int., 2011, 37, 532-556. http://dx.doi.org/10.1016/j.envint.2010.11.007

38. V. Ducrot, A. R. R. Péry, H. Quéau, R. Mons, M. Lafont and J. Garric, Sci. Total Environ., 2007, 384, 252-263. http://dx.doi.org/10.1016/j.scitotenv.2007.06.010

\section{Povzetek}

Maloščetinci selektivno privzemajo polibromirane difenil etre (PBDE), kar omogoča vrednotenje bioakumulacije posameznih kongerjev kot tudi njihovih komercialnih mešanic. Na maloščetincih vrste Tubfex tubifex smo v skladu s tehničnim navodilom OECD 315 "Bioaccumulation in Sediment-Dwelling Benthic Oligochaetes" testirali 21 BDE kongerjev iz treh komercialnih mešanic (TBDE-71, TBDE-79 in TBDE-83R) ter kot posamezne kongenerje (BDE-77, BDE126, BDE-198 in BDE-204). Vse kongenerje, ki smo jih vmešali v sediment, smo v organizmih zaznali na kocu privzemne faze kot tudi ob koncu poskusa. Izračunali smo bioakumulacijski faktor (BAF), kinetični bioakumulacijski faktor $\left(\mathrm{BAF}_{\mathrm{K}}\right)$ ter normalizirani bioakumulacijski faktor $(\mathrm{BSAF})$ ter ugotovili visok bioakumulacijski potencial za tri do heksa BDE in nižji bioakumulacijski potencial za hepta- do deka-BDE. Penta homologa BDE-99 in BDE-100 sta izkazala najvišje vrednosti BSAF in sicer 4,84 in 5,85 ob vrednostih BAF 7,34 oziroma 9,01, medtem, ko je bila bioakumulacija nona in deka BDE kongenerjev približno desetkrat nižja. Ta sprememba bioakumulacijskega potenciala med skupinama tri do heksa BDE in hepta- do deka-BDE se ujema s splošno sprejeto mejo $700 \mathrm{~g} / \mathrm{mol}$, ki velja za molekulsko maso ob prehodu bioloških membran. 
